\title{
Prognostic importance of prostate specific antigen in assessing histological grade of prostatic adenocarcinoma
}

\author{
Shanthi $\mathbf{V}^{1}$, Vydehi BV ${ }^{2}$, Bhavana $\mathrm{G}^{3}$, Swathi $\mathrm{S}^{4}$, Shehnawaz $\mathrm{B}^{5}$, Dahlia $\mathrm{J}^{6}$ \\ ${ }^{1}$ Dr Vissa Shanthi, Associate professor, ${ }^{2}$ Dr Venkata Vydehi Bheemaraju, Professor, ${ }^{3}$, Dr Bhavana Grandhi, Assistant \\ Professor, ${ }^{4}$ Dr Swathi Sreesailam, Assistant Professor, ${ }^{5} \mathrm{Dr}$ Bhat Shehnawaz, Tutor, ${ }^{6}$ Dr Dahlia Joseph, Tutor. All are \\ affiliated with Department of Pathology, Narayana Medical College and Hospital, Nellore, Andhrapradesh, India
}

Address for correspondence: Dr Vissa Shanthi, Email: santhijp@gmail.com

\begin{abstract}
Background: Prostatic adenocarcinoma is one of the most common cancer occurring in the men above 50 years of age. Prostate specific antigen (PSA) is an important serum marker which helps in the diagnosis of prostatic adenocarcinoma and also aids in estimating the tumor grade. Objective: To evaluate the correlation between serum PSA levels and Gleason's histological grade of prostatic adenocarcinoma. Methods: A retrospective study analysis was done for 128 patients whose transrectal ultrasonography (TRUS) guided prostate biopsy were studied in our hospital. The serum PSA levels were noted and compared with different Gleason histological grading in adenocarcinoma patients. Results: Our study included 128 cases, out of which 86 cases were benign and 42 cases were malignant. Maximum numbers of benign and malignant lesions were in the age group of $60-69$ years. Most of the malignant cases (80.95\%) had PSA level above $20 \mathrm{ng} / \mathrm{ml}$. Histological grade III carcinomas were restricted to PSA levels of $50 \mathrm{ng} / \mathrm{ml}$ and above, while grade I was restricted to PSA level of less than $10 \mathrm{ng} / \mathrm{ml}$ and grade II carcinomas did not have any correlation with specific PSA levels. Conclusion: Our study showed that there was significant correlation between serum PSA value and Gleasons histological grade of prostatic adenocarcinoma.
\end{abstract}

Key words: Prostate Specific Antigen, Gleason Histological Grade, Adenocarcinoma

\section{Introduction}

Prostate specific antigen (PSA) is a glycoprotein enzyme secreted by epithelial cells of the prostate. PSA is a member of the kallikrein related peptidase family which is an important tumor marker in the diagnosis of prostatic adenocarcinoma. PSA is present in serum of men, with normal prostate, but the levels are elevated in pathological conditions like prostatitis, hyperplasia and prostatic carcinoma [1]. PSA is produced by normal epithelial cells lining the prostatic glands, hyperplastic epithelial cells and pleomorphic epithelial cells in the prostatic adenocarcinoma. In conditions like inflammation, hyperplasia and malignancy, there is destruction of cell integrity which leads to release of PSA into circulation. This produces increase in serum PSA level [2].

In prostatic adenocarcinoma, the malignant cells produce less PSA then healthy epithelial cells. But as

Manuscript received: $2^{\text {nd }} \mathrm{Feb} 2015$

Reviewed: $17^{\text {th }}$ Feb 2015

Author Corrected: $11^{\text {th }}$ Mar 2015

Accepted for Publication: $29^{\text {th }}$ Mar 2015 there is great increase in number of cells in carcinoma, the PSA produced is more and serum levels are raised. The malignant cells in most of the prostatic carcinoma are immunopositive for PSA and have been used for identifying the metastatic deposits.

In protatic carcinomas, serum PSA value depends upon the differentiation of the tumor cells. The poorly differentiated prostatic tumors will have low serum PSA levels when compared to well differentiated tumors.

A pretreatment serum PSA level not only predicts the grade of prostatic adenocarcinoma but also acts as an independent predictor of response to therapy [3].

\section{Material and methods}

This is retrospective study performed at Narayana Medical college and hospital in Nellore during the period of Jan 2012 to Jan 2015. This study included 128 patients, in whom transrectal ultrasonography (TRUS) guided prostatic biopsy were taken and sent for 
histopathological examination. Minimum of ten core biopsies were taken from apex, middle region, right and left sides of base of the protate and also from the nodule if present. Biopsy was performed under ultrasound guidance using 18- gauge, Tru cut core biopsy needle which is $20 \mathrm{~cm}$ long. The specimen was sent in formalin to pathology department where they were examined for the presence of carcinoma. Preoperative serum PSA levels are noted in these cases. The prostatic biopsies which did not show malignancies were excluded and biopsies which showed malignancies were studied. PSA levels in these cases were compared with the Gleasons grade of these tumors.

\section{Results}

Prostatic biopsy specimens obtained from 128 patients who attended urology department in Narayana Medical College and Hospital were studied for the period of January 2012 to January 2015. Out of 128 prostatic biopsy specimens 86 were diagnosed as benign and 42 were diagnosed as malignancy. These cases were studied in relation to age and serum PSA levels. In malignant cases serum PSA levels were compared with grades of carcinoma.

Table 1: Prostatic lesions in relation to different age groups

\begin{tabular}{|l|l|l|l|}
\hline Age group & Total number of cases & Benign cases & Malignant cases \\
\hline $30-39 y r s$ & $1(0.78 \%)$ & 0 & $1(2.38 \%)$ \\
\hline $40-49 \mathrm{yrs}$ & $4(3.13 \%)$ & $4(4.65 \%)$ & 0 \\
\hline $50-59 \mathrm{yrs}$ & $28(21.87 \%)$ & $16(18.60 \%)$ & $12(28.57 \%)$ \\
\hline $60-69 \mathrm{yrs}$ & $52(40.62 \%)$ & $37(43.02 \%)$ & $15(35.71 \%)$ \\
\hline $70-79 \mathrm{yrs}$ & $37(28.91 \%)$ & $28(32.56 \%)$ & $9(21.43 \%)$ \\
\hline $80-89 \mathrm{yrs}$ & $5(3.91 \%)$ & $1(1.16 \%)$ & $4(9.52 \%)$ \\
\hline $90-99 \mathrm{yrs}$ & $1(0.78 \%)$ & 0 & $1(2.38 \%)$ \\
\hline Total & $\mathbf{1 2 8}$ & $\mathbf{8 6}$ & $\mathbf{4 2}$ \\
\hline
\end{tabular}

Prostatic biopsies in relation to age were studied by dividing them into 7 groups (Table 1). Maximum numbers of benign and malignant cases were in the group of $60-69$ years.

Table 2: Correlation of PSA levels with Prostate biopsy.

\begin{tabular}{|l|l|l|l|}
\hline PSA range $(\mathbf{n g} / \mathbf{m l})$ & Total number of cases & Benign cases & Malignant cases \\
\hline $0.01-3.99$ & 0 & 0 & 0 \\
\hline $4.00-9.99$ & $22(17.19 \%)$ & $20(23.26 \%)$ & $2(4.76 \%)$ \\
\hline $10.0-19.99$ & $40(31.25 \%)$ & $34(39.53 \%)$ & $6(14.29 \%)$ \\
\hline $20.0-49.99$ & $29(22.66 \%)$ & $23(26.74 \%)$ & $6(14.29 \%)$ \\
\hline $50.0-99.99$ & $20(15.63 \%)$ & $6(6.98 \%)$ & $14(33.33 \%)$ \\
\hline $100.0-149.99$ & $12(9.37 \%)$ & $3(3.49 \%)$ & $9(21.43 \%)$ \\
\hline $150.0-199.99$ & 0 & 0 & 0 \\
\hline$>200$ & $5(3.9 \%)$ & 0 & $5(11.9 \%)$ \\
\hline Total & $\mathbf{1 2 8}$ & $\mathbf{8 6}$ & $\mathbf{4 2}$ \\
\hline
\end{tabular}

PSA levels in all the cases were studied (Table 2). In our study no case was found to have PSA levels less than $4 \mathrm{ng} / \mathrm{ml} .22$ cases had PSA levels in the range of $4.0-9.99 \mathrm{ng} / \mathrm{ml}$. Out of these 20 cases were benign and 2 cases were malignant. In the PSA range of $10-19.99 \mathrm{ng} / \mathrm{ml}, 40$ cases were noted, out of which 34 were benign and 5 were malignant. 29 cases had PSA values in the range of $20-49.99 \mathrm{ng} / \mathrm{ml}$, out of which 23 were benign and 6 cases were malignant. In the range of 50 - $99.99 \mathrm{ng} / \mathrm{ml}, 20$ cases were noted, out of which 6 cases were benign and 14 cases were malignant. 12 cases had PSA values in the range of 100-149.99 ng/ml, out of which 3 cases were benign and 9 cases were malignant. There were 5 cases which had PSA values of more than 200 and all were malignant. 
Table 3: Correlation between serum PSA levels and Gleason grade of prostatic adenocarcinoma

\begin{tabular}{|l|l|l|l|}
\hline PSA range $(\mathbf{n g} / \mathbf{m l})$ & Grade 1 & Grade 2 & Grade 3 \\
\hline $4-9.99$ & $2(4.76 \%)$ & 0 & 0 \\
\hline $10.0-19.99$ & 0 & $5(11.9 \%)$ & 0 \\
\hline $20-49.99$ & 0 & $7(16.67 \%)$ & 0 \\
\hline $50-99.99$ & 0 & $10(23.8 \%)$ & $4(9.52 \%)$ \\
\hline $100-149.99$ & 0 & $7(16.67 \%)$ & $2(4.76 \%)$ \\
\hline $150-199.99$ & 0 & 0 & 0 \\
\hline$>\quad 200$ & & $5(11.9 \%)$ & \\
\hline TOTAL $(\mathbf{n = 4 2 )}$ & $\mathbf{2 ( 4 . 7 2 \% )}$ & $\mathbf{3 4}(\mathbf{8 0 . 9 5 \% )}$ & $\mathbf{6}(\mathbf{1 4 . 2 9 \% )}$ \\
\hline
\end{tabular}

PSA levels in prostatic carcinomas were compared with Gleason's grade of the tumor (Table 3). Maximum numbers of prostatic adenocarcinomas were in grade 2 [34 cases (80.95\%)]. Maximum cases in grade 2 and grade 3 had PSA range of $50-99.99 \mathrm{ng} / \mathrm{ml} .2$ cases of grade 3 adenocarcinoma were in the PSA range of $100-149.99 \mathrm{ng} / \mathrm{ml}$ and 2 cases of grade 2 adenocarcinoma had PSA range of $4-9.99 \mathrm{ng} / \mathrm{ml}$.

In our study there was a good correlation of rising PSA with grade upto PSA level of 50. Beyond that PSA level, there was no significant correlation in between the PSA level and Gleasons grade.

\section{Discussion}

Prostatic carcinoma is the most common malignancy among men and is responsible for $10 \%$ of cancer deaths [4]. Prostatic carcinoma is second to lung cancer as a leading cause of cancer related deaths in men. Hormonal factors play a role in the development of prostatic carcinoma. Incidence of prostatic carcinoma is low in patients with hyperestrogenism resulting from liver cirrhosis and does not occur in eunuchs castrated before puberty. Occupational exposure, smoking, venereal diseases, sexual habits and diet do not show any demonstrable correlation with prostatic carcinoma [5].

Almost $75 \%$ of the men diagnosed with prostatic cancer are age 65 or older and the frequency increases with age. Clinical stage, Gleason's score and serum PSA are independent prognostic factors in prostatic carcinoma and help to choose a definitive treatment in carcinoma [6].

The U.S. Food and Drug Administration [FDA] in the United States has approved that the annual screening of the prostatic cancer in men of age 50 and older is by assessing serum PSA levels. If the PSA levels are between 4 to $10 \mathrm{ng} / \mathrm{ml}$, then it is considered to be suspicious and a repeat PSA test is performed. Finally prostate biopsy should be taken for histopathological analysis, if indicated [7].

PSA also known as Seminin, Kallikrein III, Semenogelase, P-30 antigen and $\gamma-$ Semino protein is a serine protease enzyme, which has its gene located on the $19^{\text {th }}$ chromosome. It is a $34 \mathrm{KD}$ glycoprotein produced by epithelial cells of prostate [8]. Papsidero in 1980 first quantitatively measured PSA in blood and its clinical use as marker of prostatic cancer was studied by Stamey [9].

In the blood normally PSA is present at very low levels of less than $4 \mathrm{ng} / \mathrm{ml}$. Increase in the serum PSA levels indicate prostatic cancer. PSA levels can also be increased in benign prostatic hyperplasia, prostatitis, irritation, and recent ejaculation [10, 11]. PSA levels can also be raised on digital rectal examination [12].

In the blood only a small amount of PSA is available freely and large amount of it is bound to the serum proteins. The ratio of free PSA to total PSA will be reduced in Prostatic carcinoma. If the ratio is less than $25 \%$ the risk of prostatic cancer increases. In men whose PSA levels are between 4 to $10 \mathrm{ng} / \mathrm{ml}$, the ratio of free to total PSA levels helps in avoiding unnecessary biopsies [13]. 
Along with measuring the free to total PSA, the measurement of proteolytic activity of the enzyme can improve the diagnostic value of the test. The proteolytically active PSA has anti-angiogenic effect and the presence of inactive proenzyme forms of PSA indicates presence of disease [14].

Table 4: Correlation between our study and other study in relation to PSA levels and malignancy

\begin{tabular}{|l|l|l|}
\hline PSA levels (ng/ml) & Our study (2012-2015) & Sladana Zivkovic (2004) \\
\hline $0.01-3.99$ & 0 & $1(2.5 \%)$ \\
\hline $4-9.99$ & $2(4.76 \%)$ & $11(27.5 \%)$ \\
\hline $10-99.99$ & $6(14.29 \%)$ & $7(17.5 \%)$ \\
\hline$>20$ & $34(80.95 \%)$ & $21(52.25 \%)$ \\
\hline
\end{tabular}

In the present study we evaluated the prognostic importance of preoperative total serum PSA levels with grades of adenocarcinoma of prostate. In our study maximum number of malignancies has serum PSA value of more than $20 \mathrm{ng} / \mathrm{ml}$ which coincided with study done by Sladana Zivkovic (2004) who got 21 cases $(52.5 \%)$ having PSA values above 20 $\mathrm{ng} / \mathrm{ml}[15]$ (Table -4).

In our study no maliganancy was detected with PSA values in the range of $0-3.99 \mathrm{ng} / \mathrm{ml}$. In our study histological grade III carcinomas were restricted to PSA levels of 50 and above, while grade I was restricted to PSA level of less than $10 \mathrm{ng} / \mathrm{ml}$ and grade II carcinomas did not have any correlation with specific PSA levels.

In studies done by Lennox Anderson Jackson et al (2012), histological grade III adenocarcinoma had a PSA range of 76 to $190 \mathrm{ng} / \mathrm{ml}$, while grade II carcinomas had PSA range of 20-100 ng/ml . Our study coincided with the conclusion drawn from the studies of Lennox Anderson Jackson et al (2012) that histologically higher grades of prostatic carcinomas are associated with higher PSA levels [16].

\section{Conclusion}

With increasing PSA levels the possibility of malignancy is more, although malignancies were seen at low PSA levels also. More over positive relation was seen between higher levels of PSA and Gleasons grade. But as the tumor becomes more poorly differentiated it may not correlate with PSA levels because the tumor cells may not produce PSA as they have lost differentiation.

\section{Funding: Nil}

Conflict of interest: None initiated.

Permission from IRB: Yes

\section{References}

1. W.J. Catalona, J.P. Richie, F.R. Ahmann, M.A. Hudson, P.T. Scardino, R.C. Flanigan, T.L. Dekernion, J.B. Ratliff, L.R. Kavoussi, B.L. Dalkin, W.B. Waters, M.T. Macfarlane, and P.C. Southwick, Comparison of digital rectal examination and serum prostate specific antigen in the early detection of prostate cancer: results of a multicenter clinical trial of 6630 men, J Urol 1994;151:1283-1290.
2. Tchetgen MB, Oesterling JE. The role of prostate specific antigen in the evaluation of benign prostatic hyperplasia. Urol Clin North Am 1995;22(2):333-44.

3. Cooperberg MR, Pasta DJ, Elkin EP et al: The University of California, San Francisco Cancer of the Prostate Risk Assessment score: a straightforward and reliable preoperative predictor of disease recurrence after radical prostatectomy. J Urol 2005; 173: 1938.

4. Ahlering TE, Skarecky DW, McLaren CE, Weinberg AC: Seminal vesicle involvement in patients with D1 disease predicts early prostate specific antigen recurrence and metastasis after radical prostatectomy and early androgen ablation. Cancer 2002; 94(6):16481653.

5. D'Amico AV, Coleman CN: Role of interstitial radiotherapy in the management of clinically organconfined prostate cancer: the jury is still out. J Clin Oncol 1996; 14:304-315

6. Partin AW, Yoo J, Carter HB, Pearson JD, Chan DW, Epstein JI, et al. The use of prostate specific antigen, clinical stage and Gleason score to predict pathological 
stage in men with localized prostate cancer. J Urol. 1993 Jul;150(1):110-4.

7. Gomella LG, Liu XS, Trabulsi EJ, Kelly WK, Myers R, Showaltar T, Dicker A, Wender R. Screening for prostate cancer : the current evidence and guidelines controversy. Can J Urol. 2011 Oct;18(5):5875-83.

8. Lilja H. Biology of Prostate Specific Antigen. Urology 2003;62(5 suppl1):27-33.

9. Kuriyama M, Wang MC, Papsidero LD, Killian CS, Shimano T, Valenzuela L, Nishiura T, Murphy GP, Chu TM. Quantitation of Prostate Specific Antigen in serum by sensitive enzyme immunoassay. Cancer Research 1980;40(12):4658-62.

10. Nadler RB, Humphrey PA, Smith DS, Catalona WJ, Ratliff TL. Effect of inflammation and benign prostatic hyperplasia on elevated serum Prostate Specific Antigen levels. J Urol 1995;154(2PE1):407-13.

11. Herschman JD, Smith DS, Catalona WJ. Effect of ejaculation on serum total and free prostate -specific antigen concentrations. Urology 1997;50(2):239-43.

12. Crawford ED, Schutz MJ, Clejan S, Drago J, Resnick MI, Chodak GW, Gomella GW, Austenfeld M,
Stone NN, Miles BJ. The effect of digital rectal examination on Prostate-Specific Antigen levels. JAMA. 1992 Apr 22-29;267(16):2227-8.

13. Catalona W, Smith D, Ornstein D. Prostate cancer detection in men with serum PSA concentrations of 2.6 to $4.0 \mathrm{ng} / \mathrm{ml}$ and benign prostate examination. Enhancement of specificity with free PSA measurement. JAMA. 1997 May 14;277(18):1452-5.

14. Mikolacjyk SD, Catalona WJ, Evans CL, Linton HJ, Millar LS, Marker KM, Katir D, Amirkhan A, Rittenhouse HG. Proenzyme forms of Prostate-Specific antigen in serum improve the detection of Prostate cancer. Clin. Chem. 2004;50(6):1017-25.

15. Sladana Zivkovic. Correlation between prostatic specific antigen and histopathological difference of prostate carcinoma. Arch oncol 2004; 12(3): 148-51)

16. Lennox Anderson-Jackson, Donovan A McGrowder, Ruby Alexander-Lindo. Prostate Specific Antigen and Gleason Score in Men with Prostate Cancer at a Private Diagnostic Radiology Centre in Western Jamaica, Asian Pacific Journal of Cancer Prevention, Vol 13, 2012,1453-1456.

\section{How to cite this article?}

Shanthi V, Vydehi BV, Bhavana G, Swathi S, Shehnawaz B, Dahlia J. Prognostic importance of prostate specific antigen in assessing histological grade of prostatic adenocarcinoma. Int J Med Res Rev 2015;3(3):268-272. doi: 10.17511/ijmrr.2015.i3.049. 